\title{
THE EFFECTS OF SUCCESSIVE THINNINGS ON THE HYPSOMETRIC FUNCTION FOR Pinus oocarpa STANDS
}

\author{
Sebastião do Amaral Machadoํㅜ, Dalmo Arantes de Barros², José Roberto Soares Scolforo² \\ Fausto Weimar Acerbi Junior ${ }^{4}$, \\ ${ }^{1}$ Forest Engineer, Ph.D. Prof., DCIF/ UFPR, Curitiba, PR, Brasil - samachado@ufpr.br \\ ${ }^{2}$ Forest Engineer, M.Sc., Companhia Brasileira de Alumínio - CBA, Poços de Caldas, MG, Brasil - \\ dalmo.barros@aluminio.cba.com.br \\ ${ }^{3}$ Forest Engineer, Dr., Prof., DCF/UFLA, Lavras, MG, Brasil - scolforo@ufla.br \\ ${ }^{4}$ Forest Engineer, M.Sc., Prof., DCF/UFLA, Lavras, MG, Brasil - fausto@ufla.br \\ Recebido para publicação: 19/02/2010 - Aceito para publicação: 18/04/2011
}

\begin{abstract}
This research aimed to test the hypothesis that successive thinnings mischaracterize the hypsometric function, and that after some thinnings the average height of the plots or of the stand $(\bar{h})$ is an unbiased estimate of the remaining tree heights $\left(\mathrm{h}_{\mathrm{i}}\right)$, that is, $\hat{\mathrm{h}}_{\mathrm{i}}=\bar{h}$. The data were obtained from Duraflora S. A. in Agudos, State of São Paulo. This data set came from the measurement of diameters and respective heights of 1,100 trees equitably distributed in 11 different treatments with ages ranging from 5 to 25 years, and number of thinnings varying between 0 (zero) and 6. The Stoffels model, previously fitted to all treatments, was used to observe the behavior of the following factors: coefficient of multiple determination $\left(\mathrm{R}^{2}\right)$, standard error of estimate in percent (Syx \%), distribution of residuals, and the significance of the $b_{0}$ and $b_{1}$ coefficients in each one of the equations. After tests it was confirmed the hypothesis that average height is a precise estimate of hi for the oldest treatments with more than 4 thinnings. This means low Syx $\%$ and unbiased estimates, that is, good distribution of residuals.
\end{abstract}

Keywords: Hypsometric curves; management regimes; plantations; Pinus oocarpa.

\section{Resumo}

Efeitos de desbastes sucessivos sobre a função hipsométrica em povoamentos de Pinus oocarpa Shiede. Esta pesquisa teve como objetivo testar a hipótese que desbastes sucessivos descaracterizam a função hipsométrica e que após alguns desbastes a altura média da parcela ou do povoamento $(\bar{h})$ é uma boa estimativa das demais alturas $\left(\hat{\mathrm{h}}_{\mathrm{i}}\right)$, isto é, $\hat{\mathrm{h}}_{\mathrm{i}}=\bar{h}$. A base de dados utilizada para testar a hipótese formulada proveio de plantios de Pinus oocarpa, pertencentes à empresa Duraflora S.A., situada no município de Agudos, sudoeste do Estado de São Paulo. Esta base consistiu da altura e diâmetro de 1100 árvores distribuídas igualmente em 11 tratamentos, com variação de idades e número de desbastes. Visando atingir aos objetivos, foi primeiramente ajustado o modelo de Stoffels, separadamente para cada um dos 11 tratamentos, com o fim de observar a tendência dos coeficientes de determinação múltiplos $\left(\mathrm{R}^{2}\right)$, do erro padrão da estimativa em porcentagem (Syx \%), a distribuição dos resíduos e a significância dos coeficientes de interseção $\left(b_{0}\right)$ e de inclinação $\left(b_{1}\right)$ em cada uma das equações. Após proceder as análises conclui-se que a medida que se aumenta o número de desbastes os $\mathrm{R}^{2}$ vão se tornando cada vez mais baixos, porém os Syx \% foram sempre inferiores a $10 \%$. Palavras-chave: Curva hipsométrica; regimes de manejo; plantações; Pinus oocarpa.

\section{INTRODUCTION}

Several different species of the genus Pinus have been widely used in high production forest plantation programs notably from 1966 onwards with the advent of the fiscal incentives law for reforestation in Brazil. The Pinus elliottii, Pinus taeda, Pinus caribea, Pinus oocarpa and Pinus patula stand out amongst other species. These are mainly cultivated in the southern states as well as in the state of São Paulo. These programs have somewhat relieved the pressure on the native forests in addition of allowing the continuity of the forest-based industrial activity in such states. 
Along with the increasing utilization of wood yielded from planted forests, there is also a growing need for the enhancement of methods that enable the quantification of the current existing stock on a forest stand accurately and at low costs. While attempting to lower the forest inventory costs on homogeneous stands, it is common to measure the diameter at breast height (DBH) of all the trees within the sample plots but failing to measure the heights $\left(h_{i}\right)$ of all the trees. The set of $h_{i}-$ DBH pairs is not only used for estimating the height of the remaining trees through the regression process but also as the second independent variable in volume equations.

The $h_{i}$ / DBH relationship, denominated hypsometric relationship has been modeled through the regression analysis since Trorey (1932). Since then, hundreds of researchers have devoted not only to the study of the modeling and the behavior of the hypsometric relationship but also to the factors that affect it. Standing out from the rest of them, the important and intensive study of Curtis (1967) can be distinguished.

A rather large number of researches on the hypsometric relationship and the height curve behavior over diameter have been carried out in Brazil, more notably from the creation of post graduation courses onwards. Amongst them, the ones carried out by Crechi et al.(1992), Cardoso et al. (1989), Machado et al. (1994), Bartoszeck et al. (2002), Soares et al. (2004), Bartoszeck et al. (2004) can be put forward.

Employing the data set described on the methodology of the present research, Barros (2000) has carried out painstaking studies on the hypsometric relationship along with its behavior towards the function adjustment as well as the effects of age, sociological position and management regimes. In his research, he inferred that the relationship between height and diameter weakened as the stands were submitted to successive thinnings, although he never deepened his studies on this specific aspect.

Even though there are other researches on general hypsometric relationship, none of them tackles the effects of successive thinnings on it. The available data set enabled the development of this research, unheard of in the forestry environment, which allowed us to make headway on the behavior of the hypsometric relationship in intensively managed forest stands.

Thereby, the main goal of this research was to test the following hypotheses:

a) Successive thinnings damage the hypsometric function in regression terms

b) After a few thinnings, the average height of the plot or stand $(\bar{h})$ is a good estimate of the other heights $\left(\mathrm{h}_{\mathrm{i}}\right)$, that is, $\hat{\mathrm{h}}_{\mathrm{i}}=\bar{h}$.

\section{MATERIALS AND METHODS}

\section{Study area location and characterization}

The data required for this study derived from Pinus oocarpa plantations belonging to Duraflora S.A., located in southwestern São Paulo State, in the municipality of Agudos. According to Golfari et al. (1978), this area can be characterized by its periodic rainfall, dry winters with hydric deficits, annual precipitation between 1,100 and $1,400 \mathrm{~mm}$, rare frosts, average temperatures ranging between 16 and $19^{\circ} \mathrm{C}$, submontane or mild humid subtropical climate. The forest covering is made up of Pluvial Ombrophilous Forest and submontane meadows with altitude of approximately 900 meters.

\section{Data collection}

The diameters (in centimeters) and the respective heights (in meters) of 100 trees for each of the 11 treatments were measured in Pinus oocarpa plantations with different ages and submitted to a different number of thinnings, according to table 1 . The sample trees were equitably distributed among all the diameter classes. The management regimes implemented in the area, as well as the related ages, number of thinnings and minimum and maximum DBHs and Heights are shown on table 1, on the results.

\section{The model}

In an extensive study about hypsometric relationship, using this same database, Barros (2000) tested 14 traditional models for each treatment. The Stoffels model $\left(\ln h=b_{0}+b_{1} \operatorname{lnd}\right)$ was employed, in which $\mathrm{h}=$ total height of the tree in meters, $\mathrm{d}=$ diameter 1,30 meters above the ground in centimeters, $\mathrm{ln}$ $=$ neperian logarithm, $\mathrm{bi}=$ parameters to be estimated. 
This model was chosen due to the fact that it is biologically logical, which will hardly ever result in significative abnormalities or distortion of estimated values through the hypsometric equation. This statement can be confirmed by the studies of Barros (2000), Bartoszeck et al (2004), Cardoso et al. (1989), Machado et al. (1994), among others. Besides, it is a simple linear model, and therefore easy to work with and analyze the behavior of its coefficients $b_{0}$ and $b_{1}$ for each treatment.

It is important to mention that on the study carried out by Barros (2000), the 14 models have been adjusted for each one of the 11 treatments, aiming to estimate the regression coefficients and the statistics of comparison between the models tested. The Stoffels model outperformed the others, which reinforces its choosing for the present study.

\section{Adjustment and accuracy statistics}

The Stoffels model's goodness of fit was tested according to the adjusted coefficient of determination, standard error of estimate in percentage and the graphic analysis of residuals per each treatment. The values of " $\mathrm{p}$ " and " $\mathrm{t}$ " for the $\mathrm{b}$ coefficients were also calculated, resulting from the adjustment of each of the 11 treatments.

Even though all the adjustment estimators are good indicators for the choice of the best model, the graphic analysis of residuals is crucial, for it allows us to detect whether there is or not bias on the dependent variable all along the regression line, or if the residuals are independent, or if there is variance homogeneity.

According to Draper; Smith (1966) the employment of the residues in the relative form (percentage), in function of the estimated dependent variable, is more suitable for providing a better idea of both the sub estimates and super estimates' dimension of the real value and the comparison between the several models adjusted. As the graphic evaluation is merely visual, it may raise doubts, hence the need to use it jointly with the statistics previously cited.

\section{RESULTS}

\section{Specifications and characteristics of the management regimes}

Before displaying the more specific analysis, in order to reach the goal of the present research work, the minimum, medium and maximum diameter and height values per treatment or management regime implemented in the area of study will be presented, characterized by different ages combined with different numbers of thinnings, as shown in table 1.

Table 1. Specifications and characteristics of the management regimes implemented in the study area. Tabela 1. Caracterização e especificação dos regimes de manejo implementados na área de estudo.

\begin{tabular}{lcccccccc}
\hline \multirow{2}{*}{$\begin{array}{l}\text { Management } \\
\text { regime }\end{array}$} & \multirow{2}{*}{$\begin{array}{c}\text { Age } \\
\text { (years) }\end{array}$} & $\begin{array}{c}\text { Number of } \\
\text { thinnings }\end{array}$ & \multicolumn{3}{c}{ DBH $(\mathbf{c m})$} & \multicolumn{3}{c}{ Height $(\mathbf{m})$} \\
\hline $\mathrm{A}$ & 5 & 0 & 4.4 & 17.5 & 20.4 & 5.2 & 9.6 & 12.7 \\
$\mathrm{~B}$ & 6 & 0 & 6.1 & 13.6 & 20.3 & 8.2 & 12.6 & 16.3 \\
$\mathrm{C}$ & 7 & 0 & 6.3 & 14.7 & 24.1 & 7.9 & 13.7 & 17.8 \\
$\mathrm{D}$ & 8 & 1 & 7.1 & 14.4 & 23.1 & 10.5 & 16.3 & 18.8 \\
E & 10 & 2 & 9.2 & 17.2 & 26.2 & 13.2 & 16.9 & 20.9 \\
F & 11 & 2 & 7.2 & 14.8 & 23.1 & 10.4 & 16.3 & 19.8 \\
G & 12 & 3 & 7.1 & 15.8 & 25.4 & 10.5 & 16.3 & 20.5 \\
H & 15 & 4 & 18 & 24.3 & 32.1 & 19.3 & 23.8 & 28.0 \\
I & 19 & 5 & 20.5 & 30.2 & 42.2 & 23 & 26.4 & 28.9 \\
J & 22 & 6 & 25 & 33.4 & 43.5 & 24 & 26.4 & 29.9 \\
L & 25 & 6 & 27.5 & 35.9 & 49 & 22.8 & 26.2 & 28.4 \\
\hline
\end{tabular}




\section{Tests with the Stoffels equation}

The Stoffels model was employed in order to examine the hypothesis that claims the thinnings deteriorate this relationship. It was individually adjusted for each treatment, whose results are displayed on table 2. Initially, a steady growth in the equation intercept values $\left(b_{0}\right)$ can be detected as the treatments get older. As for the 5-year-old treatment (treatment $\mathrm{A}$ ), the $\mathrm{b}_{0}$ value was the smallest among all the adjustments $\left(b_{0}=1.047\right)$. However, the highest intercept values were found for the treatments $I, J$ and $\mathrm{L}$ (19, 22 and 25 years); $2.9752,3.1862$ e 2.9739 respectively.

As for the straight line inclination coefficients, that is, $b_{1}$ a clear trend can be found on the $b_{1}$ decrease associated with the increase in age, ranging from 0.4964 for treatment A ( 5 years) to 0.0242 for treatment $\mathbf{J}$ (22 years). It was found that, for the treatments older than 19, the inclination coefficients tend to zero, in other words, the effect of the inclination coefficient is null, making the estimate of height in function of the respective diameters virtually constant, therefore allowing it to be represented by the average height of the forest stand.

Table 2. Stoffels equations adjusted by treatment, with respectives $\mathrm{R}^{2}$ and $\mathrm{Sxy} \%$ and $\mathrm{t}$ values. Tabela 2. Equações de Stoffels ajustadas por tratamento com respectivos $\mathrm{R}^{2}$ e Sxy \% e valores de $\mathrm{t}$.

\begin{tabular}{lcccccc}
\hline Treatment & Age & $\begin{array}{c}\text { Number of } \\
\text { thinnings }\end{array}$ & Equations & $\mathbf{R}^{2}{ }_{\text {aj }}$ & Syx $\%$ & $\boldsymbol{t}$ values for b1 \\
\hline $\mathrm{A}$ & 5 & 0 & $\mathrm{Lnh}=1.047+0.4964$ lnd & 0.663 & 9.82 & $14.008^{* *}$ \\
$\mathrm{~B}$ & 6 & 0 & $\mathrm{Lnh}=1.429+0.4262$ 1nd & 0.697 & 7.54 & $15.122^{* *}$ \\
$\mathrm{C}$ & 7 & 0 & $\mathrm{Lnh}=1.404+0.4535$ 1nd & 0.730 & 6.63 & $16.408^{* *}$ \\
$\mathrm{D}$ & 8 & 1 & $\mathrm{Lnh}=1.594+0.4136$ 1nd & 0.639 & 6.65 & $13.274^{* *}$ \\
$\mathrm{E}$ & 10 & 2 & $\mathrm{Lnh}=1.903+0.3259$ 1nd & 0.619 & 5.22 & $12.729^{* *}$ \\
$\mathrm{~F}$ & 11 & 2 & $\mathrm{Lnh}=1.775+0.3778$ 1nd & 0.708 & 5.96 & $15.548^{* *}$ \\
$\mathrm{G}$ & 12 & 3 & $\mathrm{Lnh}=1.728+0.3876$ 1nd & 0.723 & 6.88 & $16.128^{* *}$ \\
$\mathrm{H}$ & 15 & 4 & $\mathrm{Lnh}=2.171+0.3132$ 1nd & 0.413 & 5.35 & $8.402^{* *}$ \\
$\mathrm{I}$ & 19 & 5 & $\mathrm{Lnh}=2.975+0.0872$ 1nd & 0.063 & 5.29 & $2.765^{*}$ \\
$\mathrm{~J}$ & 22 & 6 & $\mathrm{Lnh}=3.186+0.0242$ 1nd & 0.040 & 4.95 & $0.625^{\text {n.s }}$ \\
$\mathrm{L}$ & 25 & 6 & $\mathrm{Lnh}=2.974+0.0819$ lnd & 0.047 & 4.50 & $2.437^{\text {n.s. }}$ \\
\hline
\end{tabular}

tabulated $\mathrm{t}$ value: $\mathrm{t}(98-0.005)=1.9845$ and $\mathrm{t}(98-0.01)=2.62$; **significant at $99 \%$ confidence level; * significant at $95 \%$; n.s. not significant

The R2 values are within the expectations for hypsometric equations for the treatments between 5 and 12 years of age and a maximum of 3 thinnings, ranging between 0.723 and 0.619 respectively for the $\mathrm{G}$ and $\mathrm{E}$ treatments. However, the R2 for the older and more thinned stands are extremely low, as shown on table 2, thus indicating the absence of regression between heights and diameters.

It is relevant to point out that the treatments with the smallest R2 are also the ones with the smallest Syx\%. This is due to the low simple correlation (r) between diameters and their respective heights. As a matter of fact, the undesirable low R2 and the desirable low Syx\% found in the older or more thinned treatments is due to the homogenization of the heights, that is, trees with different diameters may have the same heights. This means that the thinnings gradually mischaracterize the hypsometric relationship and that actually in these cases the estimated height resembles the average height. This statement can be confirmed by analyzing the graph showing the plotted heights on the corresponding diameters (Figure 1).

The figure 1 shows a natural tendency to an increase in height as the diameters grow, which can be expressed through the upward curve for most treatments as expected in the hypsometric relationship. Notwithstanding, for the older and more thinned treatments (I, J and L) the expected trend failed to show significance, with the points scattered around a straight line, parallel to the X-axis, evidencing the absence of regression between heights and diameters for such treatments, the reason why the respective R2 were so low.

These treatments also show that the dispersion of the points along the straight line is small, which explains the low Syx\%. Due to these graphic configurations, the inclination coefficients (b1) are very low and the intersection coefficients (b0) are high for these treatments, as shown on table 2. 
The b1 values are highly significant for the younger and less thinned treatments, at both the 0.05 and 0.01 significance levels, as shown o table 2. However, for the ages 22 and 25, the b1 (inclination coefficient) are not significant for both probability levels. For the age 19 the "t" test showed that the value of b1 is on the limit of significance.

The value of b1 being not significant for the older treatments is a strong indication that the equations for these treatments can be summarized as $\mathrm{Lnh}=\mathrm{Lnb} 0$, b0 being equal to the natural logarithm of the average height, which means that the average height of the plot or the stand is an unbiased estimate of all the trees there, that is, $\hat{\mathrm{h} i}=\bar{h}$. This argument endorses the behavior of the graphs on figure 1 , where a positive relationship between height and $\mathrm{DBH}$ for the treatments $\mathrm{A}$ to $\mathrm{H}$ and the inexistence of relationship between these two variables for the treatments I, J and L can be observed.
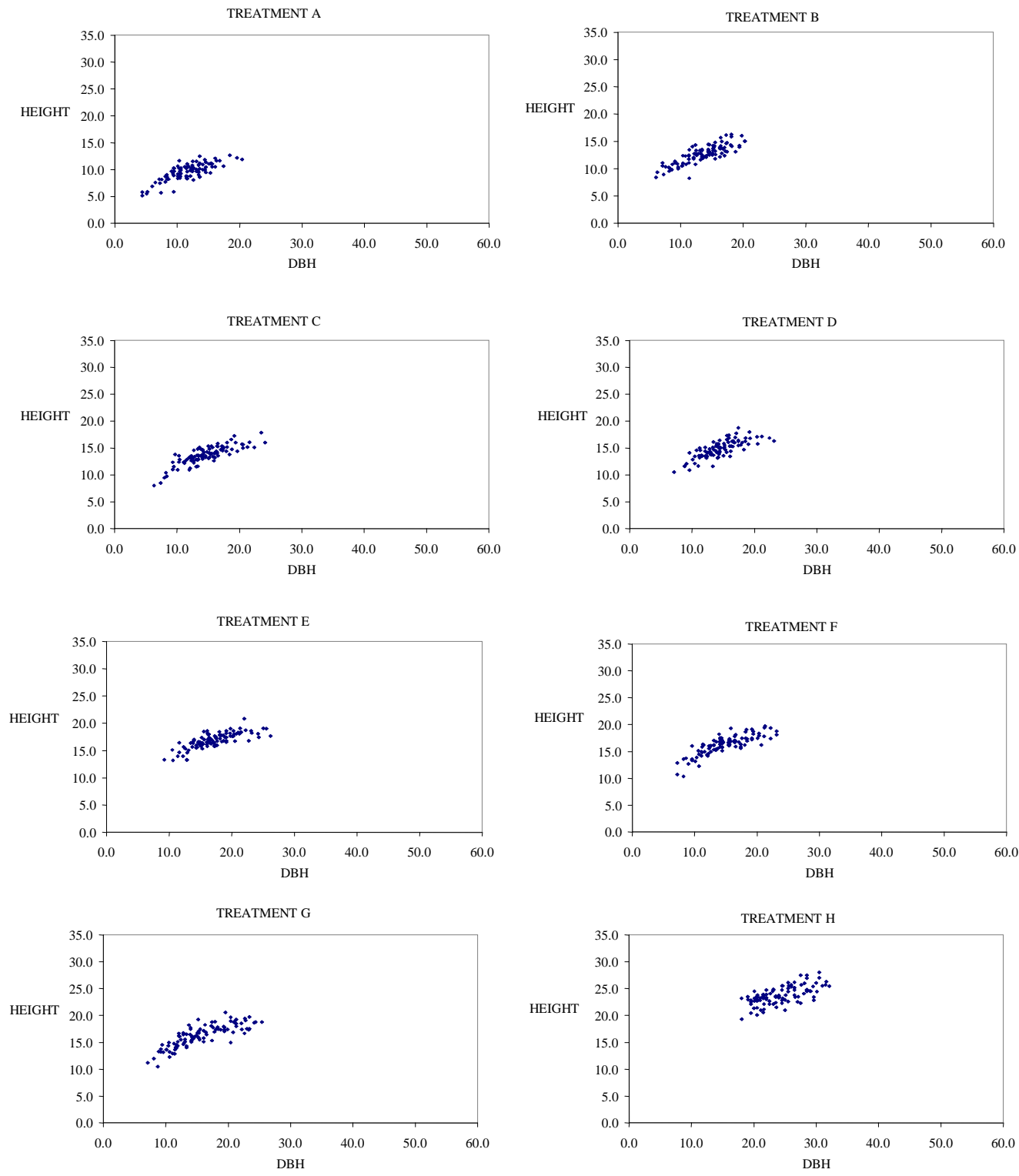

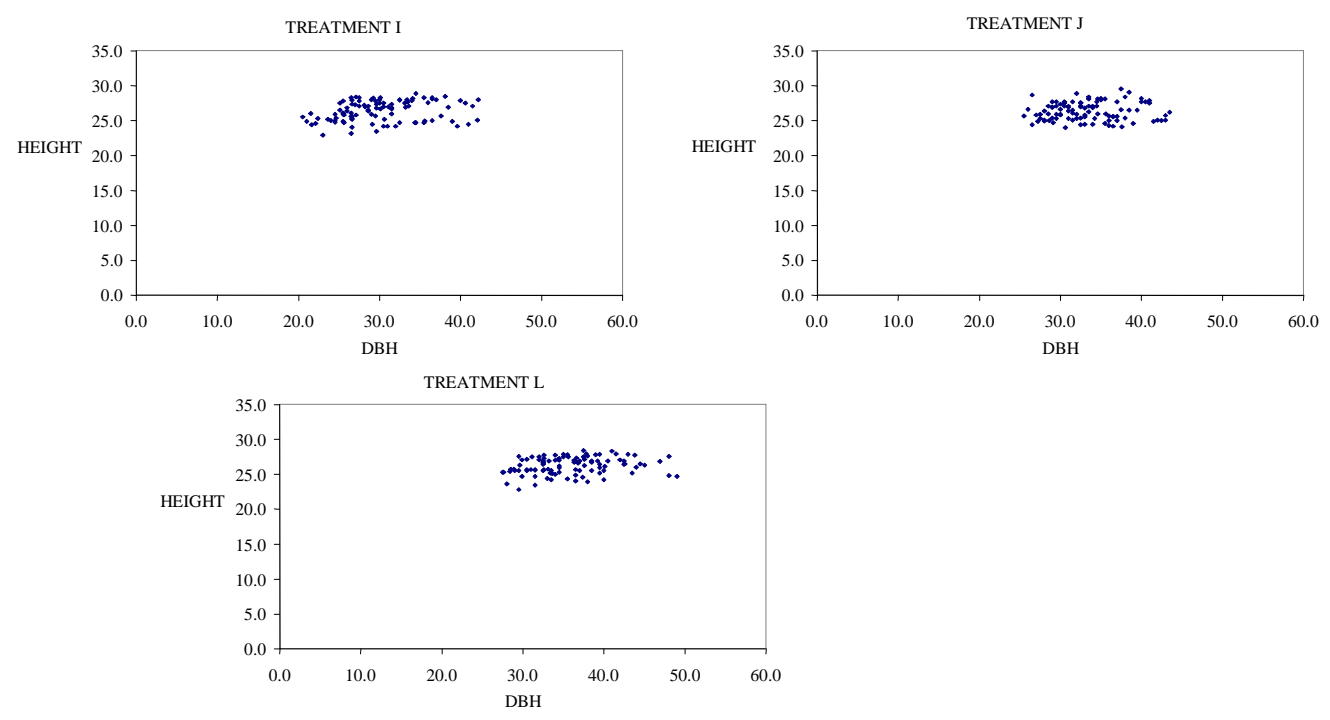

Figure 1. Graphs of height against diameter dispersion for all treatments.

Figura 1. Gráficos de dispersão da altura sobre diâmetro para todos os tratamentos.

\section{Hypothesis test}

In accordance with the goals, the hypothesis was formulated that successive thinnings in forest stands mischaracterize their hypsometric relationship. It means that over successive thinnings, the forest stand's natural structure gradually loses its features due to the human intervention, more notably when selective thinnings from below were carried out. Such interventions consist of eliminating all of the trees within the suppressed and dominated classes, only remaining the dominant trees and some of the slightly shorter codominant ones.

In fact, the low correlation and the smallest error found in the older and more thinned treatments is due to the height homogenization, in other words, trees with different diameters may certainly have the same height. That is to say, that the thinnings gradually mischaracterize their hypsometric relationship and that in fact, in these cases, the estimated height is similar to the average height. This statement can be confirmed by analyzing the graphs showing the plotted heights on the corresponding diameters for each different treatment (Figure 1), where it's possible to observe trends of the height over diameter curve. As for the older and more thinned stands the expected trend failed to show significance, with the points scattered around a straight line, parallel to the $\mathrm{X}$-axis.

In order to further investigate the statement which claims that, on the treatments with more than four thinnings, the estimated height is equal to the average height, the following hypothesis was tested for the $\mathrm{H}, \mathrm{I}, \mathrm{J}$ and $\mathrm{L}$ treatments:

$$
\hat{\mathrm{hi}}=\bar{h}
$$

$\hat{\mathrm{h}}_{\mathrm{i}}=$ estimated height (in meters) of the tree $i$

$\bar{h}=$ average height of all the trees within the sample (in meters)

In practice, due to the operational costs, it is common in forest inventories to measure the diameters of all the trees within the sample whilst measuring the height of only some of them. With that height subsample in hands, it is then possible to build the hypsometric relationship or calculate the average height for cases in which the forest stand has already undergone thinnings and there are few trees left per sample, when there is no longer a relationship between diameter and height. Besides calculating the standard error of estimate in percentage as a way to evaluate the adjustments' quality, residual distribution graphs were also used in function of the DBH (Figure 2).

It was possible to note that, for the treatment $\mathrm{H}$, the model $\hat{\mathrm{hi}}=\hat{h}$ showed a standard error of estimate of $7.02 \%$, thus acceptable, however, on the occasion of its graphic residual distribution analysis, its total inadequacy was found. The treatment $\mathrm{H}$ was solely included on figure 2 to stress that hi $=\bar{h}$ doesn't apply to it, as shown of the graph on figure 1, referring to this treatment as well as all the other younger ones. 
Note that on figure 2 the straight line originated in 0 (zero) in fact represents the average height of the respective treatments. The residuals (deviations) in percentage shown on figure 2 were calculated from the following expression:

$$
\text { Residuals } \%=\left(\frac{h_{i}-\bar{h}}{h_{i}}\right) * 100
$$

Where: $h_{i}=$ heights observed

$\bar{h}=$ average height (in this case equal to the estimated height of hi

For the treatments I, J and $\mathrm{L}$ the $\hat{\mathrm{hi}}=\bar{h}$ estimate showed a rather good performance, with unbiased residual graphs and a small amplitude on the data close to the average, and yet satisfactory errors, all inferior to 5.5\%. For the treatments I, J and L the Syx \% were 5.47\%; 4.94\% and 4.60\%, respectively. The standard error of estimate in percentage for this hypothesis was estimated from:

$$
\text { Syx } \%=\left(\frac{\left(\sqrt{\frac{\sum\left(\mathrm{h}_{i}-\overline{\mathrm{h}}\right)^{2}}{\mathrm{n}-1}}\right)}{\overline{\mathrm{h}}}\right) * 100
$$

Where: Syx $\%=$ standard error of estimate in percentage

$\mathrm{h}_{\mathrm{i}}=$ total height of the $\mathrm{i}$ tree (in meters)

$\bar{h}=$ average total height of the trees (in meters)

$\mathrm{n}=$ number of measured tree heights.

Note that on this formula $\sum\left(\mathrm{h}_{\mathrm{i}}-\bar{h}\right)^{2}$ was applied, instead of $\sum\left(\mathrm{h}_{\mathrm{i}}-\hat{\mathrm{h}}\right)^{2}$ considering that $\bar{h}$ in this case is the estimate of $h_{i}$.

Therefore, these adjustments are indicators that the previous statement is true, that is, the thinnings indeed mischaracterize the hypsometric relationship and for these cases the estimate height shows great resemblance to the average height.

It was observed that the treatments over 15 years with more than 4 thinnings, the coefficients of determination were very low. According to Machado et al. (1994) this fact can be explained based on the high data homogeneity, generated by the low variation in height, as illustrated in figure 1 . This low variation on older and more heavily thinned stands is due to the low natural correlation between diameter and height in the remaining trees.
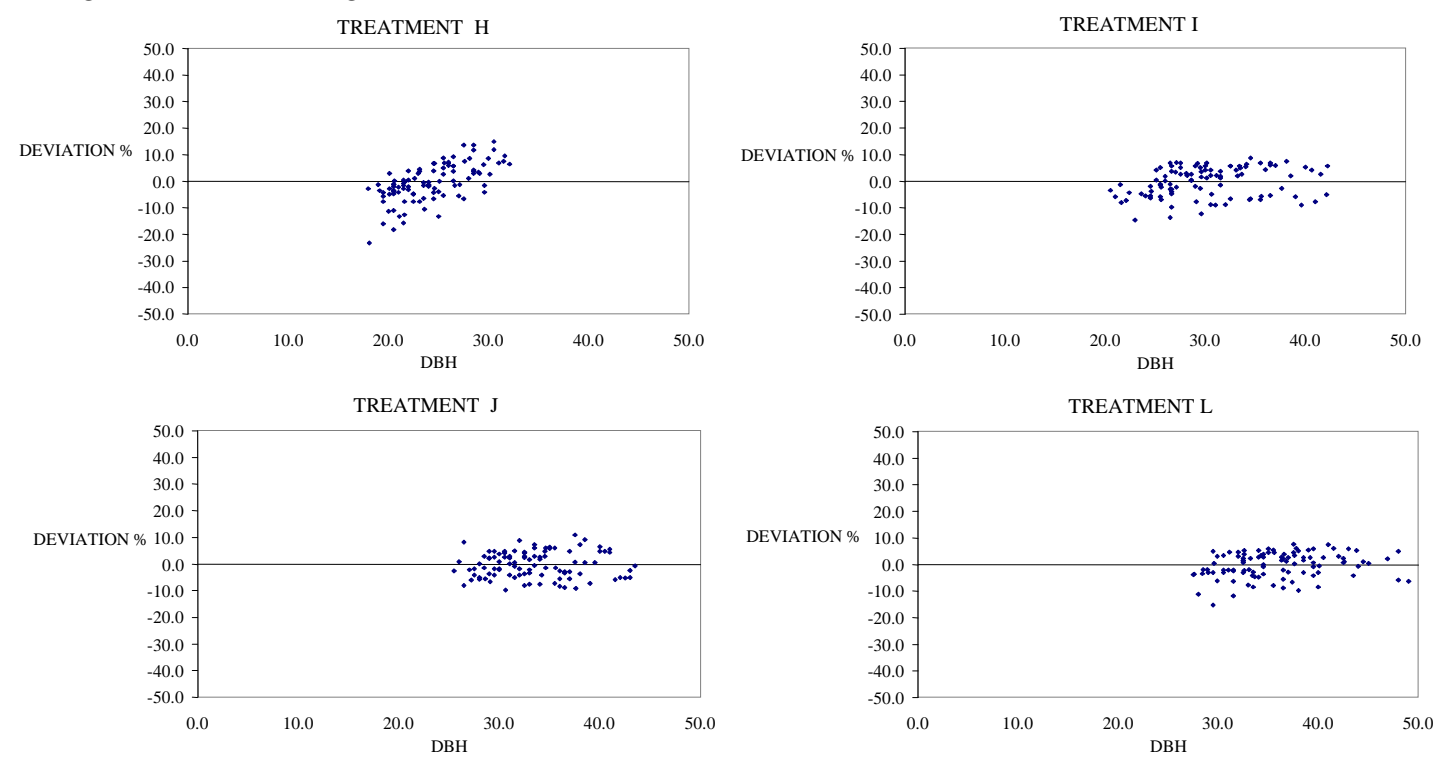

Figure 2. Graphs of residual dispersion in \% on DBH for the treatments $\mathrm{H}, \mathrm{I}, \mathrm{J}$ and $\mathrm{L}$.

Figura 2. Gráficos de dispersão de resíduos em \% em função do DAP para os tratamentos H, I, J e L.

FLORESTA, Curitiba, PR, v. 41, n. 2, p. 397-406, abr./jun. 2011. 
The $\mathrm{R}^{2}$ tends to decrease as the age increases and most importantly, the number of thinnings interventions. Nevertheless, the residual standard error tends to gradually decrease as the number of thinnings is intensified.

Over the years and the consequent thinnings interventions, a logical shortening on the length of the height curve over diameter was observed. This fact can be explained by the thinning's very own nature, which promotes the removal of the trees within the smaller diameter classes in favor of the development of the remaining ones, the reason why they tend to have their overall dimensions increased, then moving upwards toward the larger diameter classes.

\section{DISCUSSION}

Cardoso et al. (1989), using Pinus taeda data from the State of Paraná found low coefficients of determination $\left(\mathrm{R}^{2}=0.12\right)$ for the Stoffels equation for the age of 26 years. Notwithstanding, they found for the same age, low values for the estimated standard error (Syx $\%=5 \%)$. These authors justified the fact by stating that the remaining trees belonged to the dominant and codominant classes, therefore, with low variation in height. This fact can be observed at the present study with much lower $\mathrm{R}^{2}$ values for the older and more heavily thinned stands. However, the Syx\% values for these older stands are also compatible with the ones found by Cardoso et al. (1989).

Another aspect found by Cardoso et al. (1989) is that the hypsometric curves tend to move upwards and to the right, becoming increasingly more flattened as the stands become older. This particular fact was quite well evidenced at the present study, with $b_{0}$ values increasingly higher and inclination coefficient values $\left(b_{1}\right)$ increasingly lower as shown on table 2 . In the ages in which the $b_{1}$ start becoming non-significant, the estimated height hi becomes equal to $b_{0}$, this coefficient being equal to the average height as highlighted in this article.

After adjusting several hypsometric models for native stands of Mimosa scabrella - known as bracatinga - ranging between 3 and 18 years of age, Bartoszeck et al. (2002) found a slight trend of the effect of age over the adjustment and accuracy indexes, with $\mathrm{R}_{\text {adj }}^{2}$ ranging between 0.2 and 0.7 , although showing oscillations concerning age. The Syx \% also fluctuated around 10 and $16 \%$, regardless of age. Nonetheless, these authors have found that the hypsometric curve moves upwards and to the right, becoming increasingly more flattened (lower $\mathrm{b}_{1}$ ) as the stand grows older.

These facts corroborate the results found at the present work as can be seen on figure 1 as well as on table 2, although more strikingly due to the thinnings. The research of both Cardoso et al. (1989) and mainly Bartoszeck et al. (2002) show that not only the thinnings, but also the age is responsible for the hypsometric curve dynamics.

Caldeira et al. (2002), after adjusting 19 hypsometric models for Acacia mearnsii - known as Acácia negra - stands in southeastern Rio Grande do Sul with ages between 2 and 8 years and different spacings found $\mathrm{R}^{2}$ varying between 0.1 and 0.84 and Syx $\%$ around $15 \%$. The $\mathrm{R}^{2}$ values found by Caldeira et al. (2002) are compatible with the ones found in this study. Batista et al. (2001), after adjusting the hypsometric relationship for two forest typologies found $\mathrm{R}^{2}$ superior to 0.55 only for planted forests, while for native forests the $\mathrm{R}^{2}$ values were always inferior to 0.4 for the several models tested. That implies that the hypsometric relationship is not very strong, as this present study has also shown.

Testing 13 hypsometric models for Araucaria angustifólia in a fragment of Mixed Ombrophylous Forest in Curitiba, Machado et al. (2008) found extremely low $\mathrm{R}^{2}$ values, ranging from 0.17 to 0.19 for total height and 0.12 to 0.14 for trunk height. These low $\mathrm{R}^{2}$ values can be explained, according to these authors, to the low variation in height in relation to the diameters amplitude. This fact is also confirmed by this study for the older and more thinned stands.

Although a specific study on the effect of thinnings over the hypsometric relationship hasn't been found, there are strong indicators that the successive thinnings homogenize the heights within a diameter amplitude that is a little larger, flattening the curves, with the points observed around a straight line parallel to the $\mathrm{Y}$ axis as shown in figure 1, for the older ages and a larger number of thinnings. It is possible that part of the effect of age over the hypsometric relationship found by Cardoso et al. (1989) is due to the fact that the database of older forests, used by the author, derives from thinned stands. 


\section{CONCLUSIONS}

Based on the analysis, it is possible to conclude that successive thinnings in forest plantations mischaracterize the hypsometric relationship, thus confirming the hypothesis formulated in the objectives.

- The multiple determination coefficients $\left(\mathrm{R}^{2}\right)$ were low for the older and more thinned treatments, showing a low contribution of the diameter in the height estimation model, allowing us to conclude that, in these cases there is no regression between the two variables.

- Another conclusion reached was that in more thinned and older forest stands, the hypothesis that the average height is an accurate and unbiased estimate of the other heights ( $\hat{\mathrm{hi}}=\bar{h})$, is true, regardless of the DBH.

\section{REFERENCES}

BARROS, D. A. Comportamento da relação hipsométrica para plantações de Pinus oocarpa em diferentes idades e regimes de manejo. 105 f. Lavras, 2000, Dissertação (Mestrado em Engenharia Florestal), Universidade Federal de Lavras.

BARTOSZECK, A de P e S; MACHADO, S. A.; FIGUEIREDO FILHO, A.; OLIVEIRA, E. B. Modelagem da relação hipsométrica para bracatingais da região metropolitana de Curitiba, Paraná. Floresta, Curitiba, v. 32, n. 2, p. 189 - 204, 2002.

BARTOSZECK, A de P e S; MACHADO, S. A.; FIGUEIREDO FILHO, A.; OLIVEIRA, E. B. Dinâmica da relação hipsométrica em função da idade, do sítio e da densidade inicial de povoamentos de bracatinga da região metropolitana de Curitiba, PR. Revista Árvore, Viçosa, v. 28, n. 4, p. 517 - 533, 2004.

BATISTA, J. L. F.; COUTO, H. T. Z.; MARQUESINI, M. Desempenho de modelos de relações hipsométricas: estudo em três tipos de floresta. Scientia Forestalis. Piracicaba, n. 60, p. 149 - 163, dez. 2001.

CALDEIRA, M. V. W.; SCHUMACHER, M. V.; BARICHELLO, L. R.; SCHEEREN, L. W.; WATZLAWICK, L. F. Relação hipsométrica para Acacia mearnsii com diferentes idades. Boletim de Pesquisa Florestal. n. 45, jul/dez. p. 57 - 68, 2002.

CARDOSO, D. J.; MACHADO, S. A.; ROSOT, N. C.; EMERENCIANO, D. B. Avaliação da influência dos fatores idade e sítio na relação hipsométrica para Pinus taeda nas regiões central e sudoeste do estado do Paraná. Floresta, Curitiba. v. 19, n. 1-2, p. 96 - 115, 1989.

CRECHI, E. H.; FRIEDL, R. A.; FERNÁNDEZ, R. A. Evolución de la relación hipsométrica en función de la edad para Araucaria angustifolia (Bert.) O. Ktze. Yvyraretá, Eldorado, n. 3, p. 86 - 92, 1992.

CURTIS, R. O. Height diameter and height diameter age equations for second growth Douglas-fir. Forest Science, Washington, v. 13, n. 4, p. 365 - 375, 1967.

DRAPER, N.; SMITH, H. Applied regression analisys. New York: John Wiley \& Sons, 1966. 467 p.

GOLFARI, L.; CASER, R. L.; MOURA, V. P. G. Zoneamento ecológico esquemático para reflorestamento no Brasil. Belo Horizonte: Centro de Pesquisa Florestal da Região do Cerrado, 1978. 66 p.

MACHADO, S. A.; BAILEY, R. L.; BASSO, S. F.; BEVILACQUA JUNIOR, V. G. Análise do comportamento da relação hipsométrica com respeito à idade para plantações de Pinus elliottii no Paraná. Revista Cerne, Lavras, v. 1, n. 1, p. 05 - 12, 1994.

MACHADO, S. A.; NASCIMENTO, R. G. M.; AUGUSTYNCZIK, A. L. D.; SILVA, L. C. R.; FIGURA, M. A.; PEREIRA, E. M.; TÉO, S. J. Comportamento da relação hipsométrica de Araucaria angustifolia no capão da Engenharia Florestal da UFPR. Pesquisa Florestal Brasileira. n. 56, p. 5 - 16, jan./jun. 2008.

SOARES, T. S.; SCOLFORO, J. R. S.; FERREIRA, S. O.; MELLO, J. M. Uso de diferentes alternativas para viabilizar a relação hipsométrica no povoamento florestal. Revista Árvore, Viçosa, v. 28, n. 6, p. $845-854,2004$. 
